\title{
Reproductive strategy of Oreochromis niloticus (Pisces: Cichlidae) in Opa reservoir, Ile-Ife, Nigeria
}

\author{
O.O. Komolafe ${ }^{1} \&$ G.A.O. Arawomo \\ 1 Department of Zoology, Obafemi Awolowo University, Ile-Ife, Nigeria; komolafe@oauife.edu.ng
}

Received 02-X-2002. Corrected 7-I-2007. Accepted 15-I-2007.

\begin{abstract}
The fish family Cichlidae has a large diversity and dominates African freshwater bodies, with over 200 species reported in inland waters. Sampling for the fish Oreochromis niloticus (Linnaeus) in Opa reservoir, Nigeria, started in October 1997 and extended until February 2000. The fishing methods employed for collecting the 1430 specimens were cast netting and gillnetting. Egg diameter varied between $2.12 \mathrm{~mm}$ and $2.69 \mathrm{~mm}$ with a mean of $2.47 \pm 0.02$. Female gonadosomatic index was $1.34 \pm 0.01(0.12-4.06, \mathrm{n}=637)$. The male gonadosomatic index was $0.39 \pm 0.02(0.03-1.67, \mathrm{n}=789)$. In Opa reservoir, $O$. niloticus bred throughout the study period. The species was a maternal mouth brooder with the female fish carrying eggs and fry in the buccal cavities. The sex ratio of $O$. niloticus was approximately $1: 1$ in the reservoir. The fecundity of the species was between 73 eggs and 1810 eggs per female with a mean fecundity of 815 eggs. Rev. Biol. Trop. 55 (2): 595-602. Epub 2007 June, 29.
\end{abstract}

Key words: breeding season, breeding habits, sex ratio, gonadosomatic index, fecundity, Oreochromis niloticus.

The fish family Cichlidae presents an array of fishes with great diversity. These species of fish also dominated African freshwater bodies with over 200 species reported in inland waters of West Africa (Harbot 1975, Holden and Reed 1978). Breeding habits therefore differ markedly within the family (Trewavas 1983).

In Nigeria, Oreochromis niloticus is one of the dominant cichlids in inland water bodies and is of commercial importance (Arawomo 1993). Various aspects of the reproductive biology of the species have been reported by Ita (1978), Madu and Ita (1986), and Arawomo (1993). The knowledge of fish breeding habits and fecundity helps in establishing its production potential and invariably its exploitation and management. This study further examines the breeding behaviour of $O$. niloticus in a typical tropical reservoir.

\section{MATERIALS AND METHODS}

Study Area: Opa reservoir is located in Obafemi Awolowo University, Ile-Ife, Nigeria. The reservoir has a catchment area of about 116 $\mathrm{km}^{2}$ of land which extends from $7^{\circ} 21^{\prime}-7^{\circ} 35^{\prime}$ $\mathrm{N}$ and $4^{\circ} 31^{\prime}-4^{\circ} 39^{\prime} \mathrm{E}$ (Fig. 1). The surface area of the reservoir is about $0.95 \mathrm{~km}^{2}$ while the maximum capacity is about $675 \mathrm{~m}^{3}$ (Fig. 1). Minimum depth is $0.75 \mathrm{~m}$ while the maximum depth is $6.4 \mathrm{~m}$. The catchment area is characterized by annual dry and rainy seasons. The rainy seasons extends from April to September while the dry season extends from October to March.

The substratum of the reservoir is mainly mud and sand. Shoreline vegetation is dense with submerged aquatic macrophytes, some of which eventually decompose during the rainy season. 


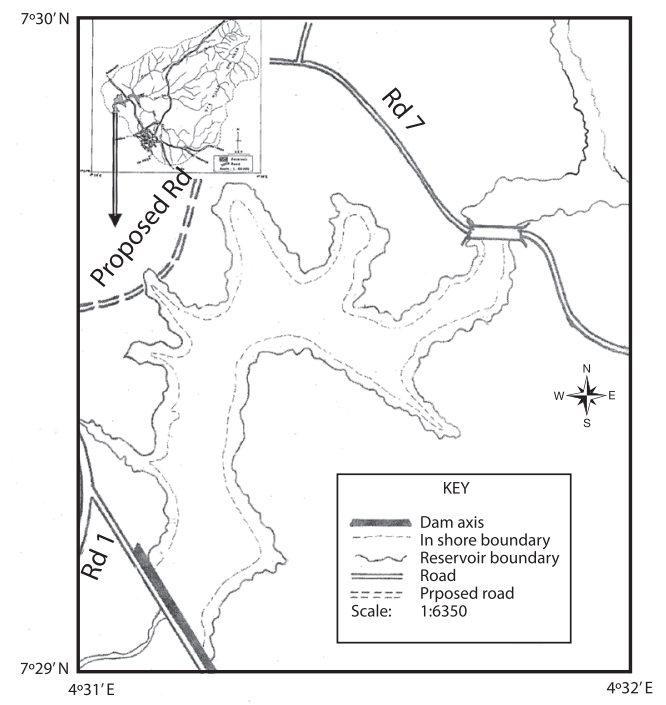

Fig. 1. Opa reservoir showing catchment (insect) and study area.

Specimens of $O$. niloticus examined for this study were caught between October 1997 and February 2000. The fish were caught either by gillnetting or castnetting. Standard morphometric parameters of each fish were taken in the laboratory. Each fish specimen was opened ventrally from the anus to the pectoral fin and its sex and stage of gonadal maturation determined visually (Roberts 1989).

All gonads were removed, weighed and gonadal stages noted (Hyndes et al. 1992). Gonadosomatic index was calculated for individual fish thus:

$$
\text { GSI }=\frac{\text { Gonad weight }}{\text { Whole fish weight }} \times 100
$$

(Bolger and Connolly 1989, Patterson 1992)

The ovaries collected from each fish specimen were preserved separately in modified Gilson's fluid (Simpson 1951, Barbieri 1989). The preserved ovaries were periodically shaken to ensure the separation of eggs from ovarian tissues. All the eggs in each pair of ovaries were determined by direct counting. The diam- eters of all eggs were measured with ocular micrometer under a binocular microscope.

\section{RESULTS}

Eggs Sizes and Sex Ratio: out of 639 female fish specimens examined, $54.5 \%$ had one batch of eggs in their ovaries while the rest had two batches. Immature stage I gonad was thread like, translucent and cream coloured with invisible oocytes. Stage II immature eggs were light yellow and round with diameters varying between $0.008 \mathrm{~mm}$ and $0.191 \mathrm{~mm}$ and a mean diameter of $0.078 \pm 0.031$. Mature eggs were yellowish and pear shaped with diameters varying between $2.12 \mathrm{~mm}$ and $2.69 \mathrm{~mm}$ while the mean was $2.47 \pm 0.02$. Eggs in the third and fourth stages of gonadal development constituted $64.8 \%$ of the total number of female eggs examined while $63.98 \%$ male fish specimens were in their third as fourth stages of gonadal development (Table 1).

Out of 1430 fish specimens examined, 791 were males and 639 females. The ratio of male fish to female fish was 1:0.8. Irrespective of whether the specimens were caught offshore or inshore by castnetting or gillnetting, the sex ratio followed the same pattern.

Gonadosomatic index: the gonadosomatic index was used to follow the seasonal development of the gonads. In the testes of male fish, gonadosomatic indices varied between 0.03 and 1.67 with a mean of $0.39 \pm 0.02$. In the female fish, the index was $1.34 \pm 0.01$ with values between 0.12 and 4.06. The monthly mean gonadosomatic indices for male and female fish specimens on stage IV gonadal development is as shown in Table 2. The gonadosomatic indices increased with the development of gonads in both male and female fish. However the indices decreased in running and spent fish (Fig. 2).

Breeding season and habits: 1430 specimens of $O$. niloticus were examined during the period of study. The males were $55.3 \%$ of the total catch. Gillnetting accounted for $57.4 \%$ 


$\begin{array}{cccccc}\text { Gonadal stages } & \text { Male } & \% & \text { Gonadal stages } & \begin{array}{c}\text { Female } \\ \text { No. fish }\end{array} & \% \\ \text { II } & \text { No. fish } & & \text { I } & 77 & 12.05 \\ \text { II } & 86 & 10.86 & \text { II } & 126 & 19.71 \\ \text { III } & 182 & 23.01 & \text { III } & 139 & 21.75 \\ \text { IV } & 225 & 28.45 & \text { IV } & 275 & 43.05 \\ \text { V } & 281 & 35.53 & \text { V } & 15 & 2.34 \\ \text { VI } & 11 & 1.39 & \text { VI } & 7 & 1.10\end{array}$

while castnetting accounted for $42.6 \%$ of the total catch. O. niloticus bred throughout the study period. There was no breeding season but peak breeding periods were observed for male fish during the month of January (1998) and August (1999). As shown in Figure 3, the female fish had peak breeding periods in June (1998), and January and July (1999). Mature male and female fish specimens had characteristics reddish-brown breeding dress

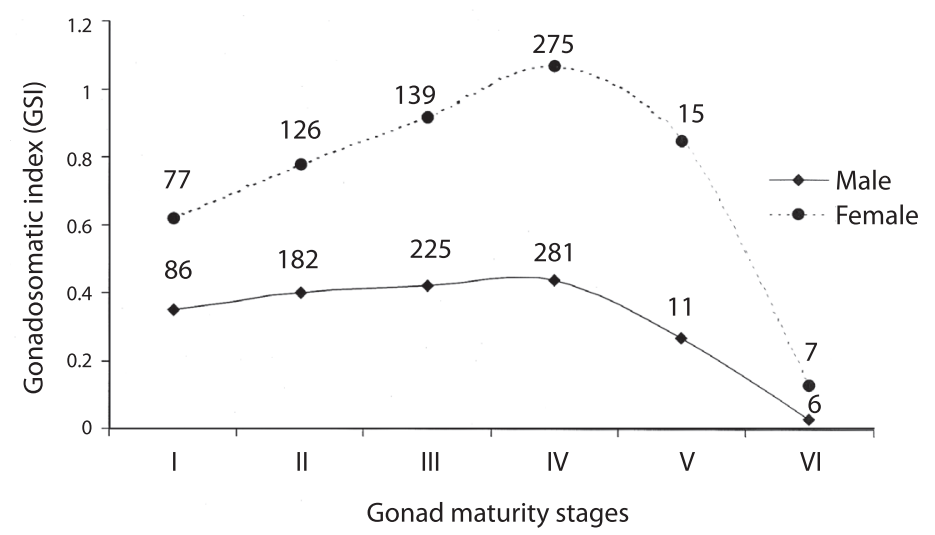

Fig. 2. Male and female GSI variation with stage of gonad maturation (values indicate number of fishes).

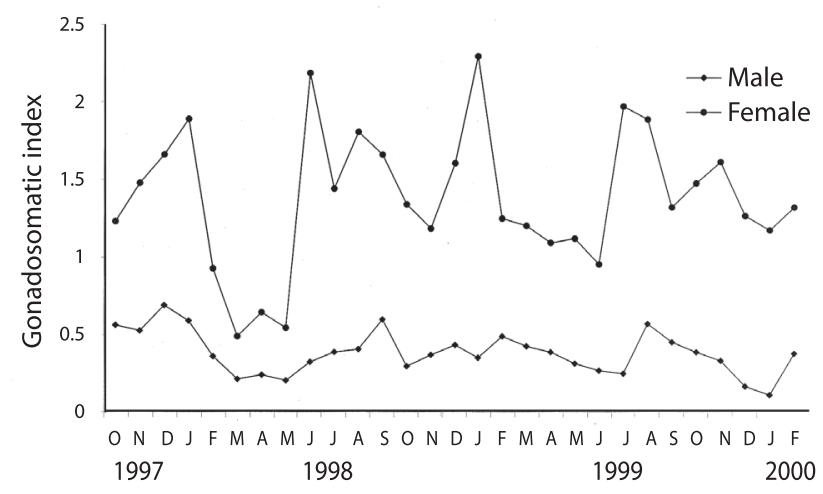

Fig. 3. Male and female $O$. niloticus in stage IV gonadal development. 
TABLE 2

Monthly variation of gonadosomatic indices

\begin{tabular}{|c|c|c|c|c|}
\hline \multirow{2}{*}{ Month } & \multicolumn{2}{|c|}{ Male Gonadosomatic indices } & \multicolumn{2}{|c|}{ Female Gonadosomatic indices } \\
\hline & Range & Mean $\pm \mathrm{SD}$ & Range & Mean \pm SD \\
\hline October 1997 & $0.39-0.75$ & $0.56 \pm 0.13$ & $1.03-2.17$ & $1.23 \pm 0.08$ \\
\hline November & $0.28-0.82$ & $0.47 \pm 0.17$ & $0.31-2.61$ & $1.48 \pm 0.66$ \\
\hline December & $0.39-1.07$ & $0.69 \pm 0.21$ & $0.50-5.33$ & $1.66 \pm 0.89$ \\
\hline January 1998 & $0.24-0.87$ & $0.59 \pm 0.32$ & $0.58-3.41$ & $1.89 \pm 0.15$ \\
\hline February & $0.62-0.74$ & $0.36 \pm 0.18$ & $0.29-4.11$ & $0.93 \pm 0.16$ \\
\hline Mar & $0.12-0.36$ & $0.21 \pm 0.07$ & $0.20-0.77$ & $0.49 \pm 0.18$ \\
\hline April & $0.11-0.80$ & $0.24 \pm 0.15$ & $0.24-1.02$ & $0.64 \pm 0.26$ \\
\hline May & $0.16-0.25$ & $0.20 \pm 0.03$ & $0.23-0.81$ & $0.54 \pm 0.29$ \\
\hline June & $0.28-0.36$ & $0.32 \pm 0.04$ & $1.32-3.28$ & $2.19 \pm 0.82$ \\
\hline July & $0.26-0.64$ & $0.39 \pm 0.15$ & $0.81-3.35$ & $1.44 \pm 0.94$ \\
\hline August & $0.31-0.48$ & $0.40 \pm 0.12$ & $1.04-3.08$ & $1.81 \pm 1.11$ \\
\hline September & $0.10-1.23$ & $0.60 \pm 1.18$ & $0.26-2.91$ & $1.66 \pm 2.49$ \\
\hline October & $0.15-0.83$ & $0.29 \pm 0.17$ & $0.72-2.15$ & $1.34 \pm 0.33$ \\
\hline November & $0.18-0.72$ & $0.37 \pm 0.16$ & $0.62-1.90$ & $1.19 \pm 0.40$ \\
\hline December & $0.16-0.75$ & $0.43 \pm 0.23$ & $0.64-4.06$ & $1.61 \pm 1.09$ \\
\hline January 1999 & $0.26-0.57$ & $0.35 \pm 0.15$ & $1.25-3.65$ & $2.30 \pm 0.94$ \\
\hline February & $0.37-0.57$ & $0.49 \pm 0.12$ & $1.02-2.22$ & $1.25 \pm 0.65$ \\
\hline Mar & $0.11-1.09$ & $0.42 \pm 0.27$ & $0.12-1.95$ & $1.20 \pm 0.40$ \\
\hline April & $0.23-0.57$ & $0.39 \pm 0.10$ & $0.81-1.39$ & $1.09 \pm 0.21$ \\
\hline May & $0.23-0.39$ & $0.31 \pm 0.06$ & $0.26-1.86$ & $1.12 \pm 0.39$ \\
\hline June & $0.20-0.35$ & $0.27 \pm 0.04$ & $0.86-1.24$ & $0.96 \pm 0.18$ \\
\hline July & $0.4-0.63$ & $0.25 \pm 0.12$ & $1.07-2.94$ & $1.98 \pm 0.76$ \\
\hline August & $0.48-0.69$ & $0.57 \pm 0.16$ & $1.17-2.59$ & $1.89 \pm 0.57$ \\
\hline September & $0.10-1.67$ & $0.45 \pm 0.54$ & $0.68-3.80$ & $1.32 \pm 0.67$ \\
\hline October & $0.26-0.65$ & $0.39 \pm 0.14$ & $1.00-2.00$ & $1.48 \pm 0.50$ \\
\hline November & $0.24-0.49$ & $0.33 \pm 0.07$ & $0.51-3.08$ & $1.62 \pm 0.72$ \\
\hline December & $0.27-0.74$ & $0.17 \pm 0.26$ & $1.02-2.72$ & $1.27 \pm 0.48$ \\
\hline January 2000 & $0.03-0.15$ & $0.11 \pm 0.06$ & $0.48-1.89$ & $1.18 \pm 0.68$ \\
\hline February & $0.26-0.78$ & $0.38 \pm 0.17$ & $1.14-1.49$ & $1.32 \pm 0.25$ \\
\hline
\end{tabular}

on the ventral surface especially around the pharyngeal region. In this study eleven female fish specimens were caught with eggs in their mouths. The measurements of the fish range from $18.0 \mathrm{~cm}$ total length, $13.8 \mathrm{~cm}$ standard length and a weight of $110 \mathrm{~g}$ to a fish of 37.7 $\mathrm{cm}$ total length, $29.7 \mathrm{~cm}$ standard length and a body weight of $969 \mathrm{~g}$. The total number of eggs found in the mouth varied from 39 to 241 .

A relatively few number of eggs in the mouth was an indication that some of them have been lost as the fish struggled for escape when captured (Fig. 4A). The serial arrangement of the eggs in the mouth was also altered. 
Throughout the sampling period only one fish specimen was caught with 46 alevins in the mouth. Some of the alevins were probably lost during capture (Fig. 4B).

Fecundity: The total length of fish specimen examined ranged from $13.7 \mathrm{~cm}$ to 31.0 $\mathrm{cm}$, total length, $10.5 \mathrm{~cm}$ to $24.4 \mathrm{~cm}$ standard length while the weight ranged from $56 \mathrm{~cm}$ to $540 \mathrm{~g}$. Total fecundity of all eggs in the ovaries ranged from 73 eggs in a fish of $18.8 \mathrm{~cm}$ total length, $15.4 \mathrm{~cm}$ standard length and a weight of $126 \mathrm{~g}$ to 1810 eggs in a fish of $29.7 \mathrm{~cm}$ total length, with $23.0 \mathrm{~cm}$ standard length and a weight of $487 \mathrm{~g}$. The mean relative fecundity was $3.34 \pm 0.11$ eggs per/g body weight of fish. Individual values of relative fecundity ranged from 0.26 eggs to $26.82 \mathrm{eggs} / \mathrm{g}$ body weight. The relationship between fecundity and standard length of fish is given as:

$\mathrm{F}=\mathrm{al}^{\mathrm{b}}$ (Bagenal 1978)

where $\mathrm{F}=$ Fecundity

$1=$ slope of the regression line

$\mathrm{a}=$ intercept of the regression line

Through logarithm transformation, the regression line becomes

$\log (\mathrm{F})=\mathrm{b} \log (\mathrm{l})+\mathrm{a}$

The relationship between fecundity and standard length for $O$. niloticus in this study is $\log F=2.425+2.67 \log 1$. A correlation factor of $r=0.370, p<0.001$ was obtained (Fig. 5). The correlation coefficient $r=0.370$ was statistically tested and significant $\left(\mathrm{t}_{\text {cal. }}=15.0>\right.$ $\mathrm{t}_{\text {tab. }}=2.617$; df 637).

\section{DISCUSSION}

Mature eggs of $O$. niloticus were yellowish and pear shaped with a mean diameter of 2.47 $\mathrm{mm}$. This was also the observation of Latif and Rashid (1972) who recorded a mean average diameter of $2.95 \mathrm{~mm}$ for the same species. In Opa reservoir, the sex ratio for the species was approximately one male to one female 1:0.8 (male to female). This result shows no signifi-
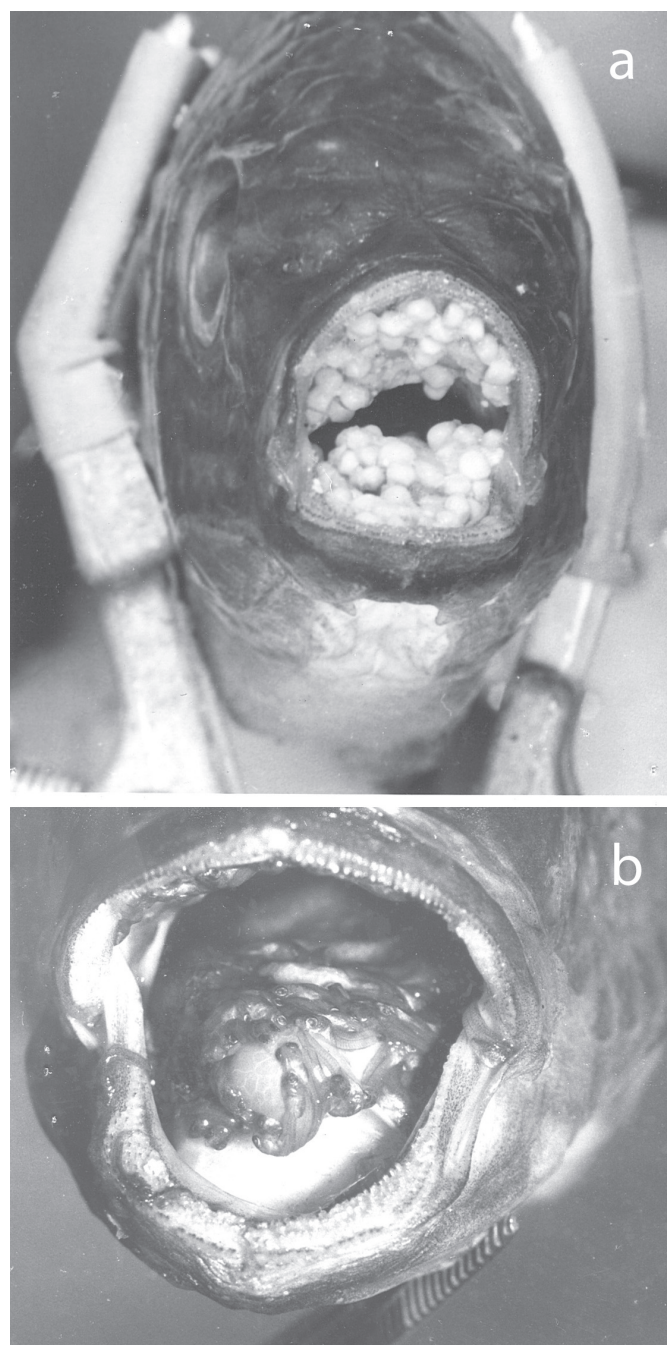

Fig. 4. Two females $O$. niloticus carring eggs (a) and alevins (b) in their buccal cavities.

cant difference as reported by Okorie (1973) for $O$. niloticus in Lake Victoria. A sex ratio of 1:1 was also reported for the species in lakes Edward and George by Fryer and Iles (1972).

The gonadosomatic index shows a steady increase in gonad maturity stages (I-IV). The drop in the indices of gonad maturity stages (V-VI) was expected. There were fewer or no eggs in the ovary after spawning. This was also reported for $T$. zillii of the same habitat (Komolafe 2004). The mean gonadosomatic indices for the male and female fish specimens 


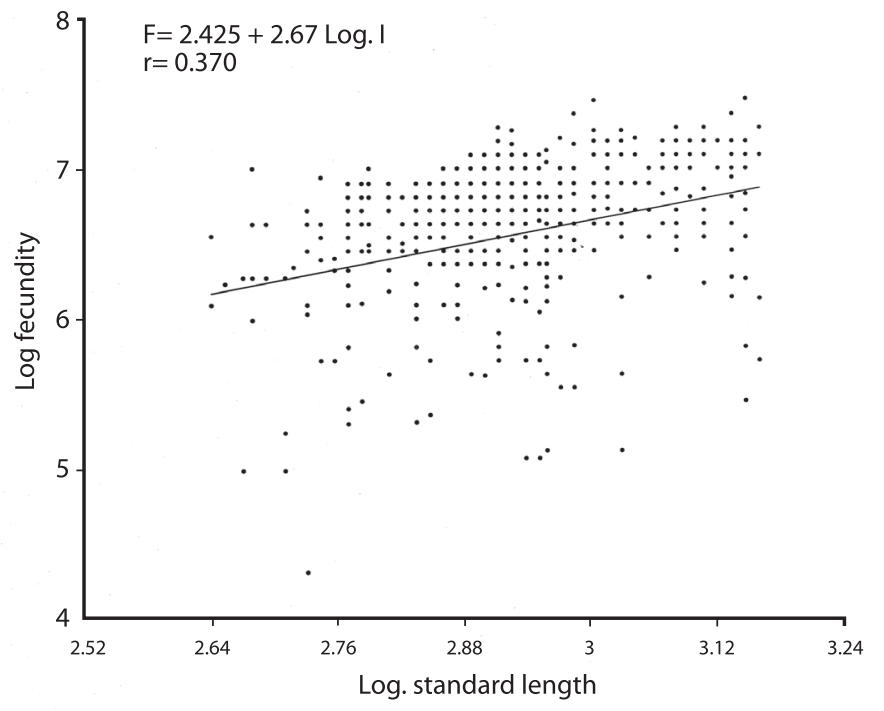

Fig. 5. Graph of Log. fecundity against log. standard length.

were 0.39 and 1.34. In the white Nile, Babiker and Ibrahim (1979) recorded 0.49 and 2.47 for male and female Tilapia nilotica. In Opa reservoir the highest gonadosomatic indices were 1.67 and 4.06 for male and female fish while the highest gonadosomatic indices for the same species showed 0.77 and 3.58 for male and female fish in the white Nile. The high gonadosomatic indices obtained in this study show that $O$. niloticus have ripe ovaries with large deposits of yolk in the eggs.

Bagenal and Braum (1978) had reported that fecundity in fish species characteristically varied among individuals of the same size and age. This was observed in Opa reservoir where the fecundity of $O$. niloticus varied between 73 eggs to 1810 eggs with a mean of 815 eggs. The result of this study is lower than what was observed in Lake Naivasha by Babiker and Ibrahim (1979) where T. niloticus have fecundity that ranged between 300 eggs and 2 800 eggs. In Opa reservoir the low fecundity of $O$. niloticus and its wide variation might be attributed to abundance of natural food materials in the habitat (Komolafe and Arawomo 2003). Fagade (1984) had also suggested that fecundity variation may be due to differential abundance of food. The low fecundity might also be attributed to the mouth breeding habits of the species and limited space available for incubation of eggs and rearing of alevins in the buccal cavity.

The presence of two batches of eggs in the ovaries was an indication that the species bred more than once in a season. Multiple spawning was also observed on T. leucosticata in lake Niavasha (Siddiqui 1977). McEvoy and McEvoy (1991) reported that multiple spawning was only possible where there was a long period of adequate food supply. The frequency of spawning in the species might be influenced by the abundance and seasonal availability of natural food materials which they selectively fed upon in the Opa Reservoir (Fawole 1995).

\section{ACKNOWLEDGMENT}

The assistance of Obafemi Awolowo University in financing this study is highly appreciated. 


\section{RESUMEN}

Estudiamos la tilapia, Oreochromis niloticus (Linnaeus) en la reserva de Opa, Nigeria, desde octubre 1997 hasta febrero del 2000. Recolectamos 1430 especímenes con red lanzada y red de arrastre. El diámetro de los huevos varía entre los $2.12 \mathrm{~mm}$ y $2.69 \mathrm{~mm}$ con un promedio de $2.47 \pm 0.02$. El índice gonadosomático de las hembras fue de $1.34 \pm 0.01(0.12-4.06, n=637)$, y en machos fue de $0.39 \pm 0.02(0.03-1.67, n=789)$. En la reserva este pez se reprodujo durante todo el periodo de estudio. Hay cuido materno: la hembra lleva los huevos y alevines en la boca. La proporción machos/hembras fue aproximadamente 1:1. La fecundidad varía entre 73 y 1810 huevos por hembra con un promedio de 815 huevos.

Palabras clave: época de reproducción, hábitos de reproducción, proporción de sexos, índice gonadosomático, tilapia, fecundidad, Oreochromis niloticus.

\section{REFERENCES}

Arawomo, G.A.O. 1993. Conservation of the freshwater finfish fauna of Nigeria, p. 97-103. In A.B.M. Egborge et al. (ed.). Proc. Natl. Conf. Conserv. Aqua. Resour, Calabar, Nigeria.

Babiker, M.N. \& H. Ibrahim. 1979. Studies on the biology of reproduction in the cichlid Tilapia nilotica (L): gonad maturation and fecundity. J. Fish Biol. 14: 437-448.

Bagenal, T.B. \& E. Braum. 1978. Eggs and early life history, p. 165-201. In W.E. Ricker (ed.). Methods for assessment of fish production in freshwaters. Blackwell, Oxford, England.

Barbieri, G. 1989. Spawning type and fecundity of three sympatric species of tropical fishes in Brazil. J. Fish. Biol. 35: 311-312.

Bolger, J. \& P.L. Connolly. 1989. The selection of suitable indices for the measurement and analysis of fish condition. J. Fish. Biol. 34: 171-182.

Fagade, S.O., A.A. Adebisi \& A.N. Atanda. 1984. The breeding cycle of Sarotherodon galilaeus in the IITA lake, Ibadan, Nigeria. Arch. Hydrobiol. 100: 493-500.
Fawole, O.O. 1995. Some aspects of the population dynamics of Sarotherodon galilaeus (Artedi) in Opa reservoir, Obafemi Awolowo University, Ile-Ife. Ph.D dissertation, Obafemi Awolowo University, Ile-Ife, Nigeria. 152p.

Fryer, G. \& T.D. Iles. 1972. The cichlid fishes of the Great Lakes of Africa. Oliver and Boyd, Edinburgh, Scotland. 641p.

Harbott, B.J. 1975. Preliminary observations on the feeding of Tilapia nilotica Linn. in Lake Rudolf. Afr. J. Trop. Hydrobiol. Fish. 4: 27-37.

Holden, M.J. \& W. Reed. 1978. West African freshwater fish (West African nature handbooks). Longman Group, London, England. 68p.

Hyndes, G.A., F.G. Neira \& I.C. Potter. 1992. Reproductive biology and early life history of the marine teleost Platycephalus speculator Klunzinger (Platycephalidae) in a temperate Australian Estuary. J. Fish. Biol. 40: 859-874.

Ita, E.O. 1978. An analysis of fish distribution in Kainji Lake, Nigeria. Hydrobiologia 58: 233-244.

Komolafe, O.O. 2004. Reproductive aspects of a cichlid fish Tilapia zillii (Gervais) (Pisces: Cichlidae) in Opa Reservoir, Ile-Ife, Nigeria. Ife J. Sci. 6: 119-122.

Komolafe, O.O. \& G.A.O. Arawomo. 2003. The distribution and feeding habits of a cichlid fish Oreochromis niloticus Linnaeus in Opa reservoir, Ile-Ife, Nigeria. Biosc. Res. Comm. 5: 379-386.

Latif, A.F.A. \& A.M. Rashid. 1972. Studies on Tilapia nilotica from Lake Nasser (1) microscopic characters of gonads. Bull. Inst. Ocean. Cairo 2: 215-138.

Madu, C.T. \& E.O. Ita. 1986. The effects of broadstock density on spawning frequency and fry production. Kainji Lake Res. Inst. Annu. Tech. Rep., Kainji, Nigeria. 230 p.

McEvoy, L.A. \& J. McEvoy. 1991. Size fluctuation in the eggs and newly hatched larvae of captive turbot (Scopthaimus maximums). J. Mar. Bio. Ass. U.K. 71: 679-690. 
Okorie, O.O. 1973. Lunar periodicity and the breeding of Tilapia nilotica in the Northern part of Lake Victoria. East. Afr. Freshwat. Fish. Res.Org. Ann. Rep. p. 50-58.

Patterson, K.R. 1992. An improved method for studying the condition of fish with an example using Pacific sardine Sardinogs sagax (Jenyns). J. Fish. Biol. 40: 429-470.

Roberts, C.D. 1989. Reproductive mode in the percomorph fish genus Polyprion Oken. J. Fish Biol. 34: 1-9.
Siddiqui, A.O. 1977. Reproductive biology, lengthweight relationship and relative condition of Tilapia leucosticta (Trewavas) in Lake Naivasha, Kenya. J. Fish Biol. 10: 251-260.

Simpson, A.C. 1951. The fecundity of Rainbow Trout Salmo qairdneri. J. Fish. Res. Bd. Can. 19: 1-27.

Trewavas, E. 1983. Tilapini Fishes of the genera Sarotherodon, Orechromis and Danakilia. British Mus. Nat. Hist., London, England. 583 p. 